\title{
New Genotypes of Leaf Mustard (Brassica juncea), Bred and Acclimatized at Vegetable Research and Development Station Buzau
}

\author{
Costel VÎNĂTORU ${ }^{1 *}$, Bianca MUȘAT ${ }^{1}$, Camelia BRATU ${ }^{1}$ Adrian PETICILĂ ${ }^{2}$ \\ ${ }^{1}$ Vegetable Research and Development Station Buzău, No. 23, Mesteacănului Street, zip code 120024, \\ Buzău, Romania \\ ${ }^{2}$ University of Agronomic Sciences and Veterinary Medicine of Bucharest, 59 Marasti Blvd, District 1, \\ Bucharest, Romania \\ *corresponding author: costel_vinatoru@yahoo.com
}

BulletinUASVM Horticulture 76(2) / 2019

Print ISSN 1843-5254, Electronic ISSN 1843-5394

DOI:10.15835/buasvmcn-hort: 2019.0016

\begin{abstract}
Since 1996, Brassicajuncea has been studied in the Breeding Laboratory of Vegetable Research and Development Station Buzau. The aim of this study was to obtain genotypes with distinct phenotypic expressivity, suitable to be grown in protected spaces and field, adapted to the pedoclimatic conditions of our country. The genetic potential of the germplasm collection was evaluated and the seven obtained families were measured biometrically and phenologically. G1 has been registered since 2017 at The State Institute for Testing and Registration of Varieties Bucharest for approval under the temporary name 'Aroma'.
\end{abstract}

Keywords: 'Aroma', genotype, phenotype, spicy

\section{Introduction}

The genus Brassica is one of the 51 genera in the Brassiceae tribe and is, economically speaking, the most important genus within this tribe, containing 37 different species (Gomez-Campo, 1980). Since 1996, Brassicajuncea has been studied in the Breeding Laboratory of VRDS Buzau. The researches aimed at acclimatizing, improving and developing the specific crop technology for this species. The plant provides edible roots, leaves, stems, buds, flowers and seed (Rakow, 2004). The oil extracted is used as a spice, similar to mustard, but with a spicier flavor. Among the seven edible oilseeds cultivated in India, rapeseed-mustard contributes $28.6 \%$ in the total oilseed production and ranks second after groundnut sharing $27.8 \%$ in the India's oilseed economy (Shekhawat et al., 2012).

Aims and objectives: Obtaining genotypes with distinct phenotypic expressivity, suitable to be grown in protected spaces and field, adapted to the pedoclimatic conditions of our country.

\section{Materials and methods}

Research has begun with a valuable germplasm collection consisting of over 20 genotypes, of which 7 have been genetically stabilized (Fig.1). Research was difficult because of the species entomophilia and therefore had to be optimally insured with specific isolation spaces. The breeding method used was repeated individual selection.

\section{Results and discussions}

The genetic potential of the germplasm collection was evaluated and the seven obtained families were measured biometrically and phenologically.

According to Table 1, differences can be seen between the studied genotypes, differences that were visible from an early stage. The observations 

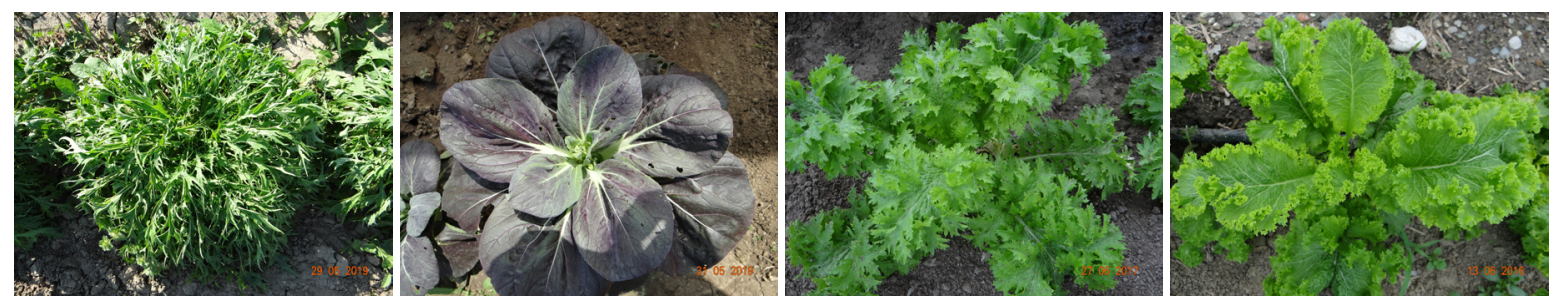

Figure1. Genotypes of Brassica juncea

Table 1. Seedlings main features measurements per each genotype

\begin{tabular}{|c|c|c|c|c|c|c|c|}
\hline \multirow{2}{*}{ Genotype } & \multicolumn{7}{|c|}{ Seedling features } \\
\hline & G1 & G2 & G3 & G4 & G5 & G6 & G7 \\
\hline $\begin{array}{l}\text { Seedling height } \\
(\mathrm{cm})\end{array}$ & 15 & 13.5 & 8.9 & 6.9 & 11 & 18 & 10.5 \\
\hline Leaf no. & 5 & 6 & 10 & 5 & 5 & 7 & 4 \\
\hline $\begin{array}{l}\text { Lamina length } \\
(\mathrm{cm})\end{array}$ & 9.4 & 9.4 & 8.9 & 3.9 & 9.2 & 11 & 7.8 \\
\hline $\begin{array}{l}\text { Lamina width } \\
\text { (cm) }\end{array}$ & 3.8 & 5.8 & 0.3 & 2.5 & 2.9 & 1.7 & 3.5 \\
\hline $\begin{array}{l}\text { Petiole length } \\
\text { (cm) }\end{array}$ & 4.7 & 4.3 & Absent & 1.9 & 2.1 & 6.5 & 2.3 \\
\hline $\begin{array}{c}\text { Anthocyanins } \\
\text { coloration }\end{array}$ & Absent & Absent & Absent & $\begin{array}{c}\text { On the upper } \\
\text { part of the leaves }\end{array}$ & $\begin{array}{c}\text { On leafs as } \\
\text { spots }\end{array}$ & Absent & Absent \\
\hline Pubescence & Absent & $\begin{array}{c}\text { On the main } \\
\text { nervure, peduncle } \\
\text { and leaf margins }\end{array}$ & Rare & Absent & Absent & Absent & Absent \\
\hline Leaf shape & Obovate & Obovate & Lanceolate & Ovate & Lanceolate & Spatulate & Ovate \\
\hline $\begin{array}{l}\text { Undulation of } \\
\text { leaf margins }\end{array}$ & $\begin{array}{c}\text { Strongly } \\
\text { undulated }\end{array}$ & $\begin{array}{l}\text { Strongly } \\
\text { undulated }\end{array}$ & Weak & Absent & $\begin{array}{l}\text { Strongly } \\
\text { undualted }\end{array}$ & $\begin{array}{l}\text { Strongly } \\
\text { undualted }\end{array}$ & Very weak \\
\hline
\end{tabular}

were made at 30 days after sowing. G6 showed the most rapid growth, with a seedling height of 18 $\mathrm{cm}$, followed by G1 with $15 \mathrm{~cm}$ height and G2 with $13.5 \mathrm{~cm}$ height. G3 presented 10 leaves, followed by G6 with 7 leaves and G2 with 6 leaves. In what concerns the lamina length, G6 was the longest, with $11 \mathrm{~cm}$ while G1 and G2 had the same length, of $9.4 \mathrm{~cm}$. Regarding the petiole length, we must observe that G3 was the only one which had no petiole The pubescence of the leaves is almost absent for every genotype. The leaf shape was an important character studied due to the fact that the interest was to obtain a genotype with a good marketable aspect, so G1 was the one that had the desired traits, with an obovate leaf that is strongly undulated.

Only genotype G1 showed a narrow variability range of the main characters. The leaves are obovate, with an erect stand short petiole and a very few number of lateral lobes. The leaf blade has a very strong blistering and the midrib width is quite narrow. This particular genotype has been tested both in protected areas and in open field, with the indication that in protected areas, from a vegetative point of view, the results showed a greater vigour of the plant. The rosette was made of large, succulent leaves, strongly corrugated. This is the reason why the succulent aromatic and spicy leaves are consumed as the plant matures, allowing the consumers to have a continuous harvest. Due to the fact that the leaves are spicy and pungent, both in protected areas and in open field no pathogens were detected to endanger the crop production.

\section{Conclusion}

Genotype 1 has been registered since 2017 at The State Institute for Testing and Registration of Varieties Bucharest for approval under the temporary name 'Aroma'. The feedback from the testing committee and from the growers whom received promotional seedlings and seeds were encouraging, the species being a real success among producers and consumers. 


\section{References}

1. Shekhawat K, Rathore SS, Premi OP, Kandpal BK, Chauhan JS (2012). Advances in agronomic management of Indian mustard (Brassica juncea (L.) Czernj. Cosson): an overview. International Journal of Agronomy.

2. Gomez-Campo C (1980). Morphology and morphotaxonomy of the tribe Brassiceae. In: Tsunoda S, Hinata
K, Gomez-Campo C (eds), Brassica crops and wild allies, biology and breeding. Japan Scientific Societies Press, Tokyo, pp 3-31.

3. Rakow G (2004). Species Origin and Economic Importance of Brassica. In: Pua EC, Douglas CJ (eds) Brassica. Biotechnology in Agriculture and Forestry, Springer, Berlin, Heidelberg, vol. 54. 